See discussions, stats, and author profiles for this publication at: https://www.researchgate.net/publication/256761868

\title{
Reevaluation of Hohenbuehelia nigra and species with close affinities. Mycologia
}

Article in Mycologia · January 1998

DOI: $10.2307 / 3761024$

CITATIONS

3 authors, including:

Edgardo Albertó

National University of General San Martín- CONICET

104 PUBLICATIONS 831 CITATIONS

SEE PROFILE

Some of the authors of this publication are also working on these related projects:

Biotechnology processes View project

Cultivation of Edible Naturally Occurring species of Mushrooms View project
13 PUBLICATIONS 97 CITATIONS

SEE PROFILE 


\section{Reevaluation of Hohenbuehelia nigra and species with close affinities}

\author{
E. Albertó \\ A. Fazio \\ J. E. Wright \\ Universidad de Buenos Aires, Facultad de Ciencias \\ Exactas y Naturales, Departamento de Ciencias \\ Biológicas, Ciudad Universitaria, Pab. II, 1428 \\ Buenos Aires, Argentina
}

Abstract: Specimens tentatively deternined as $\mathrm{Hoh}$ enbuehelia nigra var. microspora were found in the environs of Buenos Aires. Study of collections in BAFC identified by Singer as $H$. nigra showed that var. $m i$ cospora differed considerably from var. nigra. This leel to a study of the holotypes of $H$. nigra var. microspora and $H$. nigra var. nigra. In the present paper specimens of Hohenbuehelia nigra var. nigra (Schwein.) Singer are redescribed and compared with $H$. nigra sensu Singer and Digilio, and with $H$. subbarbata. The taxonomic position of $H$. nigra var. microspora Singer is defined, for which the new name $H$. singeri is proposed, whereas for $H$. nigra sensu Singer and Digilio the variety $H$. nigra var. pileocystidiata is proposed.

Key Words: Agaricales, systematics

\section{INTRODUCTION}

During a revision of the genus Hohenbuehelia in Argentina, a rather abundant species was found in the province of Buenos Aires, which we tentatively determined as $H$. nigra var. microspora Singer, belonging to subg. Hohenbuehelia Stirps Atrocaeruleus (with nonpetaloid habit) (Singer, 1975). The study of a few collections in BAFC identified by Singer as $H$. nigra showed that var. microspora differed considerably from variety nigra, which prompted us to consider var. microspora as an autonomous species. This led us to study the holotype specimens of $H$. nigra var. $m i$ crospora and $H$. nigra var. nigra.

Hohenbuehelia nigra was originally described as Agaricus niger by Schweinitz (1822). Fries (1828) validated it as Agaricus (Pleurolus) niger. Saccardo (1887) recorded it as Pleurotus niger. Coker (1944)

Accepted for publication September 2, 1997

' Enuil: ed@bg.fcen.uba.ar cited the species as Pleurolus niger Schwein. for North Carolina; his description was actually based on a study of the Schweinitz holotypes extant at BPI and PH. Libonati-Barnes (1981) indicated two interpretations of $H$. nigra: one by Coker (1944) and another by Singer and Digilio (1951) who also pointed out that the type of Agaricus subbarbalus Berk. \& Curtis from Cuba was very similar to Hohenbuehelia nigra (Schwein.) Singer.

In the present paper we redescribe the type of $H$. nigra, and we compare it with $H$. nigra sensu Singer and Digilio and with H.subbarbala. In addition, we definc the taxonomic position of $I I$. nigra var. microspora Singer and $I /$. Migra sensu Singer and Digilio, for which we propose a new name with rank of species for the former, and a new variety of $H$. nigra for the latter.

\section{MATERIALS AND METIIODS}

Collected specimens were described macroscopically in situ, then refrigerated for further microscopic examination in the laboratory. Color determination followed Munsell (1954). Abbreviations of author's names are according to Kirk and Ansell (1992). Freehand sections of specimens were mounted in $10 \%$ KOH plus $1 \%$ aqueous solution of phloxine. All collections are deposited in the mycological Herbarium, Dept. de Ciencias Biológicas, Facultad de Ciencias Exactas y Naturales, University of Buenos Aires (BAFC). Herbaria abbreviations follow Holmgren et al. (1990).

\section{RESULTS}

\section{KEY TO TAXA TREATED}

1. Pileocystidia absent; leptocystidial pleurocystidia present; spores 4-5(-5.5) $\times 3-5 \mu \mathrm{m} . . . . . . .4$. singer

1. Pileocystidia present, leptocystidial pleurocystidia absent, pleurocystidia metuloid; spores $>6 \mu \mathrm{m}$ long $\quad 2$ 2. Pileocystidia globose to pyriform, thin walled; pleurocystidia hyaline .......... H.sublarbala 2. Pileocystidia metuloid, if globose then thickwalled; pleurocystidia brown $\ldots \ldots \ldots \ldots \ldots \ldots$

3. Two types of pileocystidia present; cutis formed by only one type of hyphae ... H.nigra var. pileocystidiala 
3. One type of pileocystidium present; cutis formed by three types of lyphae $\ldots \ldots \ldots \ldots$ H.nigra var. nigra

Hohenbuehelia nigra (Schwein.) Singer, Lilloa 22: 256. (1949) 1951.

FIGS. 1-7

$\equiv$ Agaricus niger Schwein., Syn. Fung. Car.: 90. 1822.

$\equiv$ Pleurotus niger (Schwein.) Saccardo, Syll. Fung. 5: 380.1887.

$\equiv$ Resupinatus niger (Schwein.) Murr. N. A. F. I. 9: 242. 1915.

Pileus 3.5-7 mm diam, convex, circular, pseudostipe not observed, attached to substratum by the underside of the pileus, pruinose, very dark gray (5YR 3/1) at the base and black (5YR 2/1) towards the margin, lighter in the center due to a whitish pruina that becomes less abundant towards the margin until finally glabrous; margin crenulate, concolorous with pileus. Lamellae adnexed with elcentric attachment, close to distant, very dark gray (5YR 3/1); margin entire. Context appearing gelatinous in section when soaked, concolorous with pileus. Spores (Fic. 2) 7-7.5 $\times$ 4-4.5 $\mathrm{mm}$, short ellipsoid, thin-walled, hyaline, fusoid, smooth, nonamyloid. Basidia (FIr. 2) 20-23 $\times$ 6.5-7.5 $\mu \mathrm{m}$, clavate, 4-spored. Basidioles (FIc: 3) 25$30 \times 4-5 \mu \mathrm{m}$, with gelatinizing walls up to $3 \mu \mathrm{m}$ thick. Pleurocystidia pseudocystidiate (FIG. 5) metuloid, 50-70 $8-14 \mu \mathrm{m}$, projecting ca $20 \mu \mathrm{m}$ above the hymenium, with the basal portion immersed in the trama and usually recurved, very thick-walled, brown, darker at the base; pigment cytoplasmatic, becoming lighter to hyaline towards the apex; apex extremely acute, encrusted with small, nonamorphous polyhedric crystals. Cheilocystidia of identical shape and size. Pileipellis a cutis formed by three types of closely interwoven generative hyphae: (i) $2-5 \mu \mathrm{m}$ diam, thick-walled, brown, clamped (FIG. 4), whose ends form structures similar to mycosclereids (Wright, 1955), very irregular in shape, 13-17 × 3.5$10 \mu \mathrm{m}$ (FIC. 7); (ii) 1.5-2 $\mu \mathrm{m}$ diam, hyaline, clamped, thin-walled, and (iii) 1.5-2 $\mu \mathrm{m}$ diam, hyaline, clamped, thick-walled (FIG. 1). Pileocystidia (FIC. 6) metuloid, 22-32 $\times 8-10 \mu \mathrm{m}$, with a brown, thick wall and more or less blunt apex with encrusted crystals all along the cystidium. Context formed by a loose trama of clamped hyphae $1.5-2.5 \mu \mathrm{m}$ diam with thin, gelatinized walls.

Material studied. Agaricus niger Schwein., U.S.A., North Carolina, Salem, HOLOTYPE PH, ISOTYPE BPI.

Remarks. This species is characterized by basidionata of small size, black pileus, clark lamellate, very large, dark brown metuloid cystidia and the presence of metuloid pileocystidia which Coker (1944) consid- ered an infrequent character. The holotype material is scant but well preserved. It lacks a pruina, a feature which, according to Coker (1944), would be present in young specimens. The spore length he recorded is larger $(7.4-9.5 \mu \mathrm{m})$ than our measurements $(7-7.5$ $\mu \mathrm{m})$, otherwise we agree with Coker's concept of Hohenbuehelia nigra. Both collections studied (BPI and $\mathrm{PH}$ ) are identical.

Miller (1986 and personal comm.) purports that the correct name for this species ought to be $H$. niger based on Art. 73 of the 1966 version of the International Code of Botanical Nomenclature (Lanjow, 1966) which governs the orthography of names and epithets, and the gender of generic names. We are unable to support this view since Hohenbuehelia is a feminine noun and thus the specific epithet must be declined in accordance, hence Agaricus niger becomes $H$. nigra as correctly stated by Singer (1951) and Dennis (1970), among others (cfr. Greuter (1994), Art. 60.1, 60.2 and also Recom. 60E,1 and Art. 23.5). This would also be the case of $H$. cristosa (bas. Pleurotus crustosus); H.stratosa (bas. P. crusto sus); $H$. geogenia (bas. $P$. geogenius); $H$. inversa $(P$. inversus); H. mastrucata (Agaricus mastrucatus); $H$. atrocoerulea (A. atrocoeruleus); $H$. silvana ( $A$. silvanus), which appeared in Miller (1986), and whose epithetic desinence has not been questioned.

\section{Hohenbuehelia nigra (Schwein.) Singer var. pileocys- tidiata Fazio \& Albertó, var. nov. \\ Fics. 8-15 \\ $=$ Hohentuehelia nigra (Schwein.) Singer sensu Singer
and Digilio, Lilloa 25: 117. 1951.}

A typo differt pileocystidia duorum: a) normales ut in H.nigra; b) globosis, hyalinis, leviter crasse tunicatis. Cutis tantum hyphis hyalinis; basidiis longiorum usque ad $40 \mu \mathrm{m}$; basidiolis pariete gelineae absunt.

HOLOTYPUS. ARGENTINA, Bonariae, Berazategui, Parque Pereyla, Singer \& al., 20-VI-62, BAlC 33.232.

Basidiocarp 5-7 $\mathrm{mm}$ diam, pileate, conchate, with lamellate hymenophore, appressed to substrate by margin of pileus. Lamellae black (7,5 YR 2/0), distant to subdistant; lamellae margin light brown (7,5 YR 6/4). Spores (FIG. 15) 6.8-8.3 $\times 3.6-4.7 \mu \mathrm{m}$, ellipsoid to subcylindric, hyaline, smooth, nonamyloid. Basidia (FIG. 15) 25-40 × 5-6 $\mu \mathrm{m}$, fusiform, 4-spored; sterigmata 5-6 $\mu \mathrm{m}$ long. Basidiole walls not gelatinized. Pleurocystidia pseudocystidiate, metuloid (FIGs. 10, 11), 43-65 $\times 10-15 \mu \mathrm{m}$, brown, with very acute thinwalled apices, with small encrusted crystals in the: "1pper portion, measuring $5-8 \mu \mathrm{n}$ diann without crystals. Pileipellis cutis of hyaline, thick-walled, clannped hyphae, 2-3 $\mu \mathrm{m}$ diam (FI(. 9). Pileocystidia of two types: some sphaero-pedunculate, $28-30 \times 14-16$ 


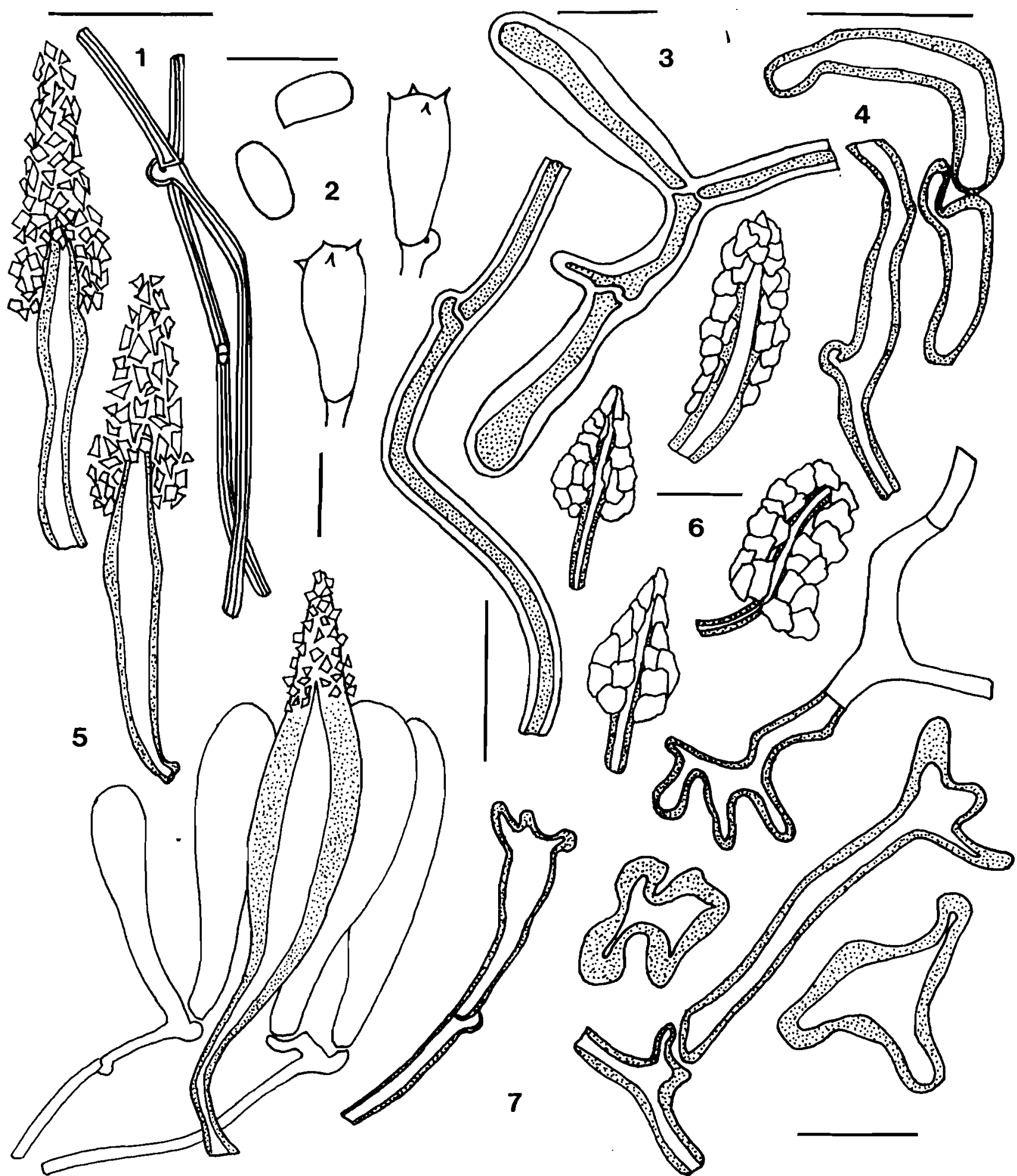

Fics. 1-7. Hohenbuehelia nigra var. nigra (type specimen). 1. Pileipellis hyphae. 2. Basidia and basidiospores. 3. Hyphae and basidioles with gelatinized walls. 4. Pileipellis hyphae. 5. Metuloids. 6. Metuloid pileocystidia. 7. Mycosclereids. Scale bars $=10 \mu \mathrm{m}$. 

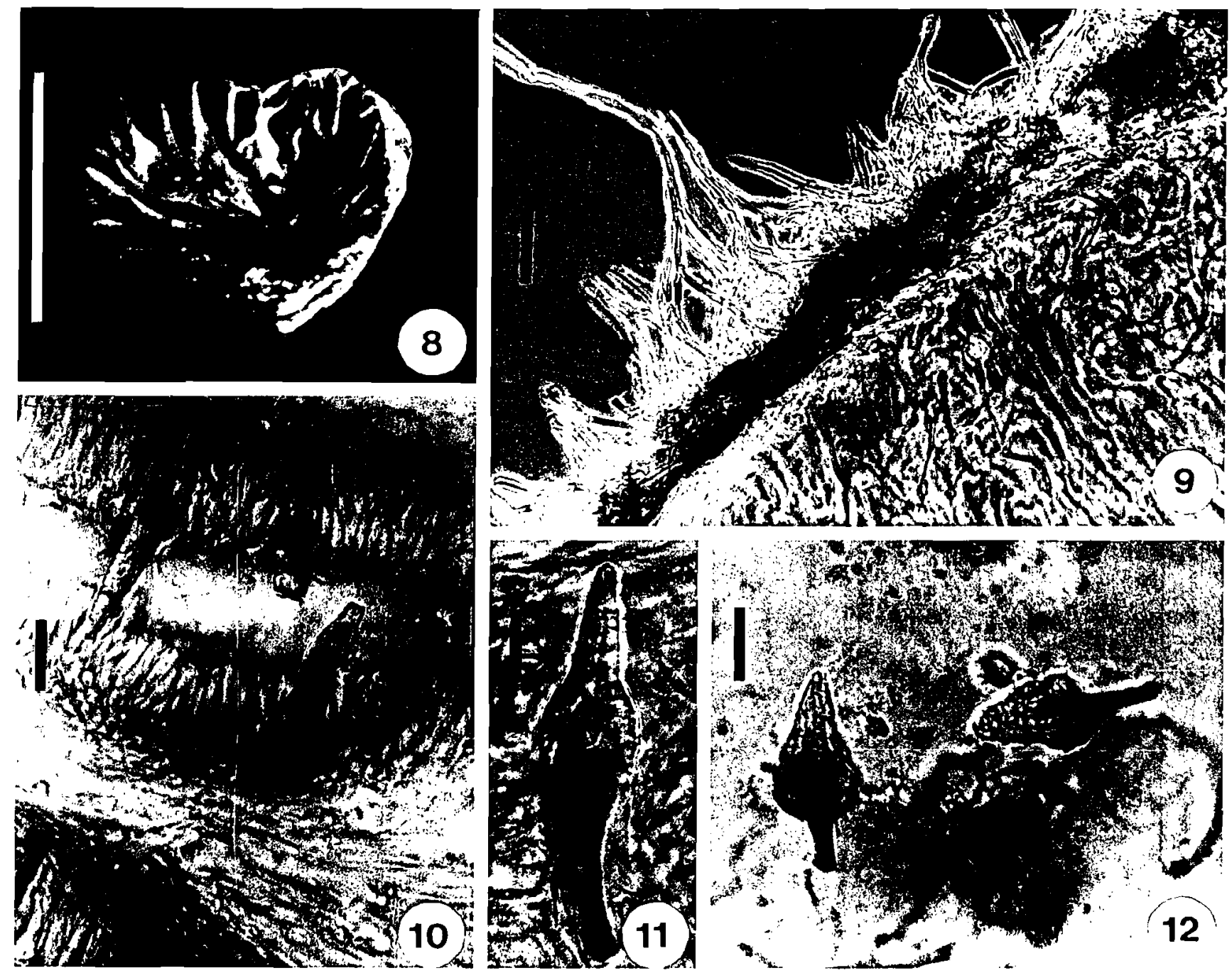

Fic:s. 8-12. Hoheninehelia nigra var. pileocystidiata (type specimen). 8. Basidioma. 9. Section of the pileus showing hyphac of the pileipellis and gelified hyphac of the trama. 10, 11. Metuloid pseudocystidia, 12. Metuloid pileocystidlia. Scale bar: Ficis. $8=5 \mathrm{~mm} ., 9,11=10 \mu \mathrm{m} ., 12=15 \mu \mathrm{m}, 10=20 \mu \mathrm{m}$.

$\mu \mathrm{m}$, scattered, hyaline, with slightly thickened walls (FIG. 13), and others metuloid $40-45 \times 10-16 \mu \mathrm{m}$, with crystal encrustations (FIG. 12). We have observed in the cutis structures appearing as mycosclereids (Wright, 1955), 10-15 × 8-10 $\mu \mathrm{m}$, irregular in shape, yellowish brown, with very thick walls (Fic. 14).

Material studied. The holotype.

Remarks. Unfortunately we have been unable to study the original material on which Singer and Digilio (1951) based their description and which was deposited in LIL; this material must be presumed lost. Singer (1969, p. 61) recorded the only extant collection of H.nigra from Argentina (see citation of material above) under this epithet and we have based our description on this collection.

This variety is macroscopically identical with var. nigra but has some micromorphological differences.
It is characterized by the presence of hyaline, thickwalled, clamped hyphae in the cutis; two types of pileocystidia, one metuloid and the other sphaeropedunculate, and slightly thick-walled (the latter are absent in H.nigra sensu Coker); and nongelatinized basidioles.

Singer and Digilio (1951) also indicated that $H$.nigra was very similar to $H . s u b b a r b a t a$. An analysis of the holotype of H.subbarbata and a comparison with H.nigra is presented below.

Hohenbuehelia subbarbata (Berk. \& Curtis) Sing., Lilloa 22: 255. (1949) 1951.

FIGS. 16-21

$\equiv$ Agurims subbarbatus Berk. \& Curtis, J. Linn. Soc. 1301. 10: 288. 1869.

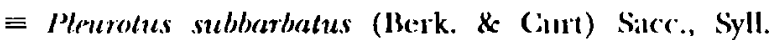
liung. 5: :383. 1887. 


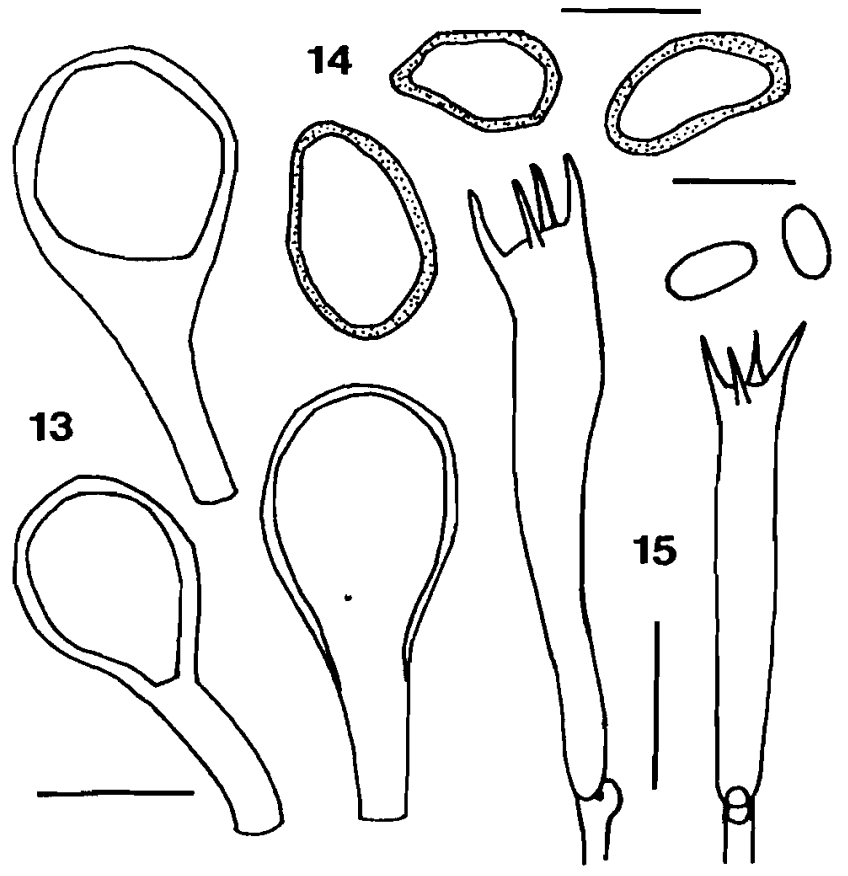

Ficis. 13-15. Hohentnuehelia nigra var. pileocystidiala. 13. Sphacropedunculate pileocystidia type, 14. Mycosclereids. 15. Basidia and basidiospores. Scalc bars $=10 \mu \mathrm{m}$.

\section{$\equiv$ Resupinatus subbarbatus (Berk. \& Curtis) Murr., N. American flora 11: 242. 1915.}

Basidiocarp 3-6 mm diam, semicircular to flabelloid, slightly pruinose on the surface; margin undulate, fuscous to fuscous-black; flesh dark gray, entirely gelatinous. Lamellae decurrent, crowded, narrow, concolorous. Pseudostipe tomentose with a white pruina or efflorescence at the base. Spores (FIG. 18) 6$6.7 \times 3.5-4 \mu \mathrm{m}$, ellipsoid, smooth, hyaline, nonamyloid (only 5 spores seen). Basidia $22 \times 10 \mu \mathrm{m}, 4$ spored. Basidioles 18-20 $\times$ 4-5 $\mu \mathrm{m}$. Cheilo- and pleurocystidia (Fıs. 19) metuloid, (30-) 45-70 × 12-15 $\mu \mathrm{m}$, abundant, ventricose to fusiform, scantily encrusted with crystals, hyaline to light yellowish; walls thin, medium to very thick with the latter more abundant, often becoming thinner-walled towards the base. Pileipellis a cutis of hyaline, clamped, thinwalled hyphae, $2 \mu \mathrm{m}$ diam (FIG. 21); pileocystidia subglobose to pyriform, $14-20 \times 10-12(-18) \mu \mathrm{m}$, thin-walled, abundant, with a clamp at the base (FIG.17), mainly hyaline but also some with brown content.

Material studied. CUBA, Wright 808, K 39.995 (HOLOTYPE).

Remarks. Hohenbuehelia subbarbata is characterized by basidiomata with black pileus, slighty hispid surface and tomentose at the base, dark lamellae, and very characteristic metuloids, with a very thick, hyaline wall, thin lumen and a hyaline base. In addition,

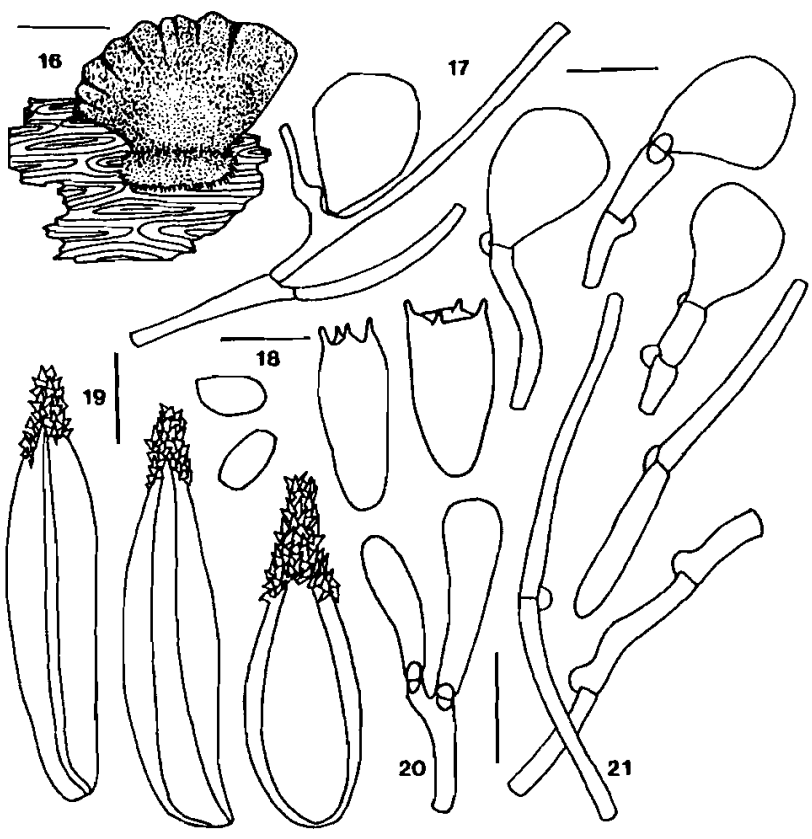

lìı is. 16-21. Hohenimehelia subbarbala (type specimen). 16. Basidioma. 17. Globose, thin-walled pileocystidia. 18. Basidia and basidiospores. 19. Metuloid pleurocystidia. 20. Basidioles. 21. Pileipellis hyphac. Scale bars $=10 \mu \mathrm{m}$ except FiG. $16=2 \mathrm{~mm}$.

the species has globose, thin-walled pileocystidia, and small elliptical spores. The holotype material is scant, and not well preserved, making confirmation of the tomentose surface of the pileus difficult to observe.

Hohenbuehelia singeri Albertó \& Fazio, nomen nov Figs. 22-32

$=H$. nigra var. microspora Sing., Mycologia 47: 763 1955; non $H$. microspora (Speg.) Sing., Fieldiana Bot. 21: 42, 1989.

Basidiocarp (FIG. 22-26) up to $5 \mathrm{~mm}$ diam, circular to petaloid, subconchate to scutellate, subumbonate, pruinose, velvety, stipe absent, adhered to substrate by the central or sublateral dorsal portion, light gray (7.5 YR, 7/0) due to the presence of a white pruina which disappears towards the margin, in adult specimens very dark gray (5YR, 3/1) to blackish, hygrophanous, with a gelatinous aspect when soaked; margin acute, slightly pruinose and light grey when young, generally naked (pruina absent) in adult specimens, and then blackish. Flesh gelatinized, $0.5 \mathrm{~mm}$ thick in the widest portion becoming thinner towards the margin. Lamellae insinuated as a corrugation on the abhymenial surface, up to $0.7 \mathrm{~mm}$ wide, entire, interspersed with more or less distant lamellulae, black to very dark grey (5YR, 3/1) becoming lighter (7.5 YR, 5/4) towards the smooth margin. Spores 


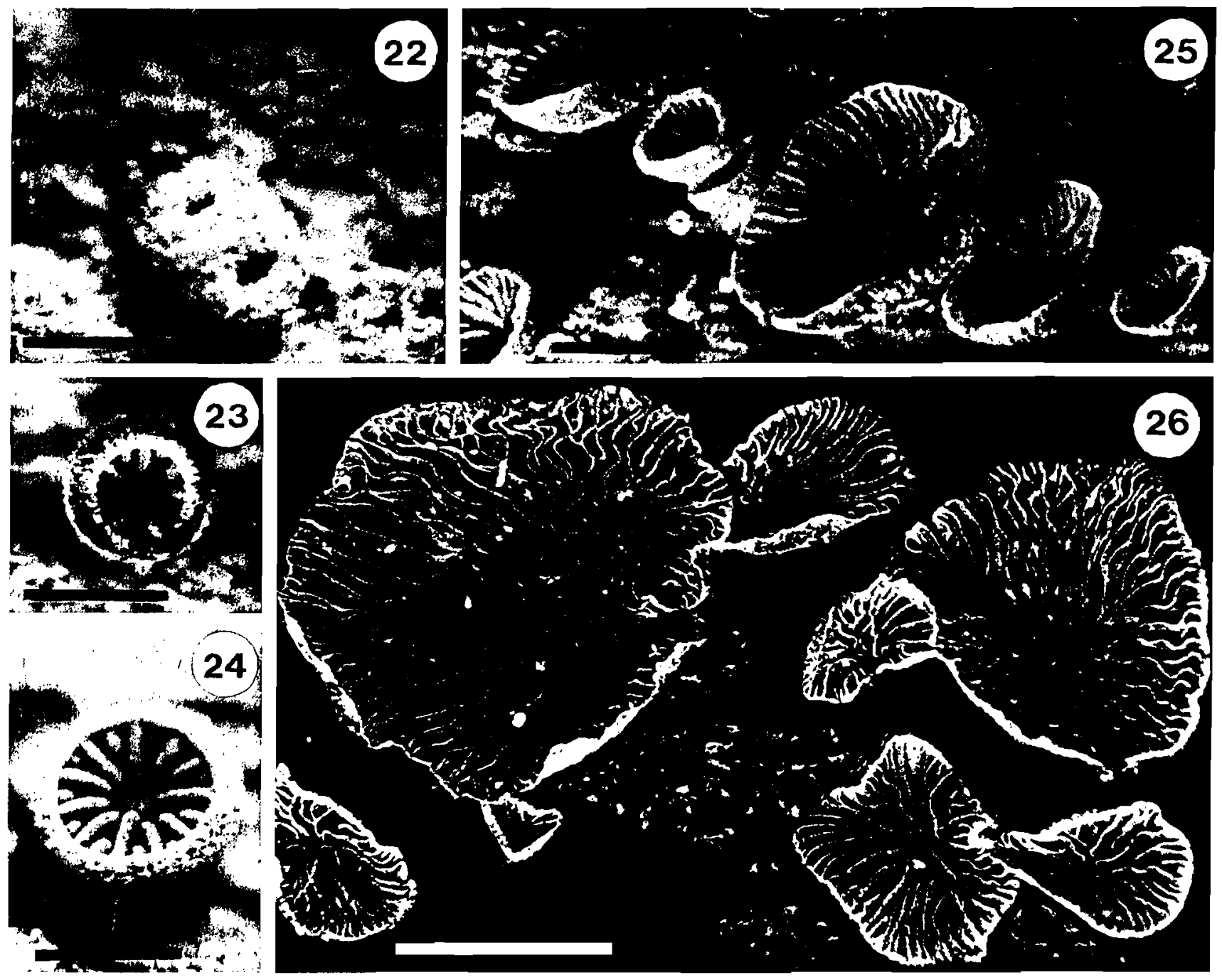

FIcs. 22-26. Different states of development of the basidiomata of Hohenbuehelia singeri. 22. Initial state (primordia); note that it is completely covered by a white pruina. 23. Intermediate state I: The pileus begins to expand. 24 . Intermediate state II: Iamellae begin to differentiate. 25. Advanced state. 26. Basidiomata completely developed. Scale bars $=2 \mathrm{~mm}$.

(FIG. 29) 4-5(-5.5) $\times$ 3-3.5 $\mu \mathrm{m}$, ellipsoid, smooth, hyaline, nonamyloid, with guttulae. Basidia (FIC. 29) 13-17 $\times$ 4-6 $\mu \mathrm{m}$, clavate, 4-spored. Pleurocystidial leptocystidia appearing metuloid in Melzer's reagent 30 $60 \times 10-25 \mu \mathrm{m}$ (FIc. 31) encrusted with amorphons crystalline substance, crystals soluble in $\mathrm{KOH}$; cystidial walls thin to slightly thickened, 20-40 $\times 4-12$ $\mu \mathrm{m}$ without crystals (FIG. 32)' Subhymenium very dense, formed by short and nodulose hyphae. Pileipellis formed by three types of hyphae: (i) thinwalled, hyaline, clamped, somewhat branched, 1.5$2.5 \mu \mathrm{m}$ diam. (FIc:30); (ii) thick-walled hyaline, clamped, slightly or not branched 3-4 $\mu \mathrm{m}$ diám. (FIG. 27), and (iii) thick-walled, with brown intraparietal pigment, clamped, tortuous and branched, 3-4 $\mu \mathrm{m}$ diam (FIG. 28). Pileocystidlin absent. Context hyphae immersed in a gelatinous matrix, abundantly clamped, thin-walled, up to $3 \mu \mathrm{m}$ diam. Lamellae tra- $m a$ irregular, of clamped, hyaline hyphae up to $4 \mu \mathrm{m}$ diam, immersed in a gelatinous matrix.

Material studied. ARGENTINA, Buenos Aires, Delta, INTA, E. Albertó, 11-II-94, BAFC 33.301; Burzaco, E. Albertó, 7-VI-93, BAFC 33.305; Buenos Aires, Llavallol, Sta. Catalina, E. Albertó, 27-I-94, BAFC 33.299; 4-IV-94, BAFC 34.356; 4 VI-94, $B A F C$ 34.359, Buenos Aires, Llavallol, Sta. Catalina, A. Fazio, 3-V-94, BAFC 34.357, BAFC 34.358, BAFC 34.360 and $B A F C$ 34.361; Buenos Aires, Llavallol, Sta. Catalina, $E$. Fernández, 16-VI-94, BAFC 34.355; Buenos Aires, Llavallol, Sta. Catalina, A. Sosmousky, 22-VI-96, BAFC 34.362. PANAMA, Corundú, Martin and Welden (no. 8.353), 13-VIII-52 (Holotype of H.nigra var. microspora; F).

Remarks. This species is characterized by a dark pileus with cinereous hues due to the presence of a whitish pruina abundant in young specimens (FIcis. 22-24), total absence of pileocystidia, small spores, and the presence of two types of pleurocystidia, (i) 


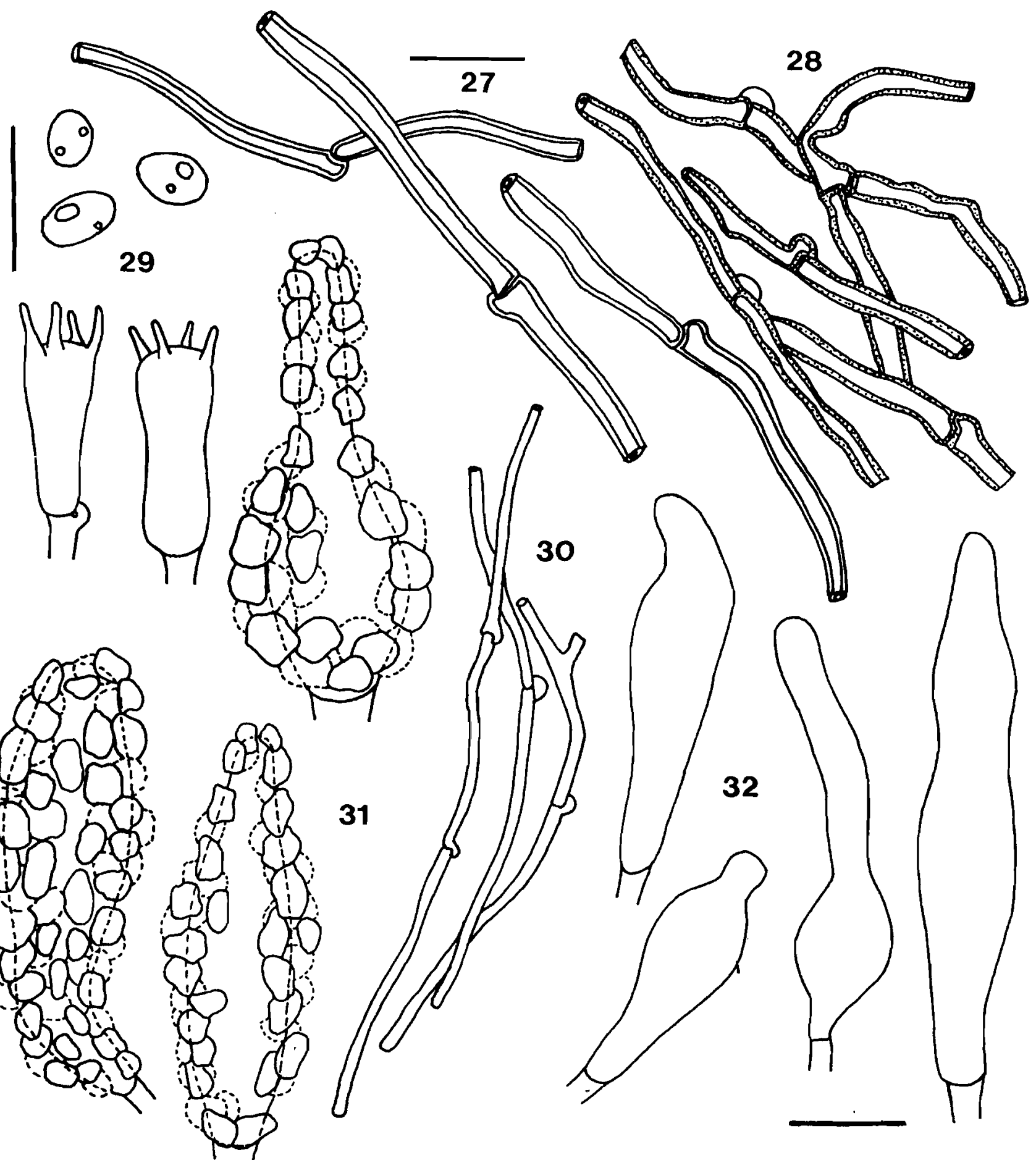

Figs. 27-32. Hohenbuehelia singeri. 27, 28. Pileipellis hyphae. 29. Basidia and basidiospores. 30. Pileipellis hyphae. 31. Leptocystidial pleurocystidia covered with amorphous crystals. 32. Leptocystidial pleurocystidia without crystals. Scale bar: FiGs. 27, 28, $30=15 \mu \mathrm{m} ., 29,31,32=10 \mu \mathrm{m}$.

abundant leptocystidia with thin walls and (ii) scant cystidia, with only slightly thickened walls; both types covered by a sheath of amorphous, opaque crystals (FIG. 31) that dissolve in $\mathrm{KOH}$ (FIG. 32). The opaque crystals do not allow the observation of cystidial walls.
When a fresh slide of the lamellae is observed under the microscope, the crystals become loose and fall off; as a consequence these can be seen as skull-caps slowly moving along the slide; after a few minutes they are completely dissolved. 
Development of basidiomata follows a simple gymnocarpic: pancern: (i) an incipient romoled, woolly, sessile fruibody (primordia) with a central opening (FII; 22) in which the lamellae appear later (FIC. 23); (ii) an intermediate state I, as tan outgrowth of the pileus inargin, centripetally extend (FIC. 24); (iii) an intermediate state II until the lamellae reach the micklle point, corresponding roughly to the umbo by which the fruitbody adheres to substrate (FIs: 25); (iv) fully cleveloped fruitbodies with sinuous lamellae probably due to contraction of tissues (Frs: 26).

\section{DISCUSSION}

H. nigra (Schwein.) Singer sensu vero vs. I-I. nigra (Schuein.) Singer sensu Singer and Digilio.-Singer and Digilio (1951), for the most part agreed with Coker (1944), although with some minor differences in basicliocarp ancl spore size, probably the result of varying clegrees of basidiocarp maturation. They suggested that the Argentine material could be a form of Scliwcinite's Hohenlneehelia nigra. Furthermore, they only observed one type of metuloid pileocystidia in the Argentine material. Singer and Digilio (195I) reported that their specimens measured 4-12 $\mathrm{mm}$ clian, with spores $6.8-7 \times 3.5-3.8 \mu \mathrm{m}$, in contrast 10 the measurements of $H$. nigra given by Coker (1944), viz. basidiomes $3.5-7 \mathrm{~mm}$ diam and spores $7-7.5 \times$ 4-4.5 $\mu \mathrm{m}$.

Even though we have studied only one specimen of each species, after a comparative stucly we observed significative differences between the specimens. The type material of Hohenbuehelia nigru has the cutis formed by three types of hyphae, whose thick-walled brown ends form well-defined mycosclereids; has only metuloid-type pileocystidia; basidia up to $23 \mu \mathrm{m}$ long; and gelatinized basidioles. In conparison, H.nigra sensu Singer and Digilio has the cutis formed by only one type of hyaline, thick-walled liyphac, whose ends form scant, differently shaped mycoesclereids (cf. FIGS. 7, 14), two types of pileocystidia (one metuloid and another sphaero-pedunculate, hyaline, with slightly thickened walls), basidia II) to $40 \mu \mathrm{m}$ long, and has nongelatinized basidioles. We consider these differences taxonomically signifcant and accept $H$. nigra sensu Singer and Digilio as a clistinct variety of $H$. nigra, which we name pileocyslidiala.

H. nigra (Schwein.) Singer sensu Singer and Digilio vs. I. subbarbata (Berk. $\mathcal{F}^{2}$ Curtis) Sing.-Singer and Digilio (1951) pointed om that the type of $A$ garicus subbarbatus Berk. \& Curtis from Cuba was very similar (o) Iohenbnehelia nigra (Scliwein.) Singer, but A. sub bavthatus appeared to have: a slightly hispid pileus sur- face, the spores measured $6.7 \times 4-4.2 \mu \mathrm{m}$, and the metuloids reached $75 \times 14 \mu \mathrm{m}$. Moreover, muless the constant presence of pileocysticlia and larger spores in all specimens could be proved, they would feel inclined to recognize all of them as forms of the same species.

Dennis (1953) redescribed the holotype of P.subbarbatus (Berk. \& Curtis) Sacc. but later (Dennis, 1970) considered this name synonymous under H.nigra (Schwein.) Sing. Comparing the type materials we concluded that although macroscopically these specimens are very similar, the metuloids and spores are different enough to separate them. Hohenbuehelia nigra has metuloid pseudocysticlia (50-70 $\times 8-14 \mu \mathrm{m})$ with very thick, brown walls, and short ellipsoid spores $(7-7.5 \times 4-4.5 \mu \mathrm{m})$ (FIc.. 5), whoreas H.subbarbata has metuloids $((30-) 40-70 \times 12-15$ $\mu \mathrm{m})$ also with very thick walls but which are liyaline to light yellowish (Fic. 19), and snatler spores (6-6.7 $\times 3.5-4 \mu \mathrm{m})$. The pileocysticlia are also different; the type specimen of H.subbarbata has only onc type of pileocysticlia that are subglobose or pyriform and thin-walled (Fis. 17). The type specimen of H.nigra var. nigra has also only one type but it is metuloid whereas the specimen of $H$. nigra sensu Singer and Digilio has two types of pileocysticliat: a menuloid type (FIc. 12) and a subglobose or pyriform type but with thick walls (FIG. 13). It may be argued that the scant number of spores found in the holotype of $H$ s sub barbata could be attributed to the immaturity of the batsicliocarps. However, we consider that the clifferences between pileo- and pleurocysticlia of both $H$. subluarbata and H. nigra var: nigra, pointed out albove, are not due to the possible immaturity of $H$. subbarbata; thus we believe they are independent taxa.

1.I. nigla (Schwein.) Singer sensu vero vs. H. nigra vor: microspora Sing.-Macroscopically basidiomata of both taxa are similar, although $H$. nigra var. microspona has smaller basidiomata will a more abuncliut white pruina in young specimens (FIGs. 22-24). Microscopically, however, the differences are conclusive. The examined specinen of variety nigra has spores measuring 7-7.5 $\times 4-4.5 \mu \mathrm{m}$, brown-walled metuloid pseudocystidia, measuring 50-70 $\times 8-14 \mu \mathrm{m}$ with regular and rhombic crystals and a recurved base (FIG. 5), whereas var. microspora has smaller spores $(4-5(-5.5) \times 3-3.5 \mu \mathrm{m})$ and hyaline metuloid cystidia measuring 30-60 $\times 10-25 \mu \mathrm{m}$ covered with amorphous crystals that dissolve in KOH (FICs. 31, 32). Furthermore, $H$, nigra var. microspora lacks pileocystidiat.

Based on the above featmes, we believe that vall microspora deserves specilic rank. Ilowever, the specilic epithet microspore is preocoupied by $I I$. micor- 
spora (Speg.) Sing. based on Pleutrotus portegnuss Speg. var. mirrosperra Speg. thitu. Singer (1989) raised (o) specific rank. We therefore name this species $I$. singeri in honor of the late mycologist Dr. R. Singer.

\section{AC:KNOWI.EI)GMENTS}

We wish to thank Dr. E. Horak (ETHS, Zürich), who confirmed our iclentification of H.nigra var, microspora. We also want to thank the curators of F, BPI, K, LIL, and PH for the loan of specimens in their keeping. Drs. R. Petersen (TENN) and Dennis Desjarclin (SFSU) kincly read the typescript and made valuable suggestions. Photographs were processed at the Instituto Fitotécnico de Santa Catalina (University of $l_{\text {a }}$ Plata). This research was financed by the Argenuine: Nal'l Resc:arch Coumcil (C.ONICET); pal)er no. 104 of the PRIIIDEIS.

\section{IITERATURE (ITTED}

Coker, W. C. J. 1944. The sinaller species of Ileutohus in North Carolina. I. Kilisha Milrhell Sri. Soc. 60: 71-95, pl. 40-52.

Dennis, R. W. G. 1953. Some pleurotoid fungi from the West Indies. Kerv. Bull. 1: 31-45.

- 1970. The fungus flora of Venezuela and adjacent countrics. Kewv Bull., Adllit. Ser. 3: 1-531.

Frics, E. 1828. Elenchus fungomum, sistens commentarius systematis mycologicum 1. Gryphistualidiae. $238 \mathrm{pp}$.

Greuter, W. (Ecl.). 1994. International code of bolanical nomenclatum. Kodi\%. Scientilic Boskss, Königstcin, Gormany. $389 \mathrm{Pl}$.

Holmgren, P. K., N. II. Holmgren, and L. (.. Barnett. 1990).
Index herbariomum. 8th ed. New York Botanical Garden. Now York. (69)3 pl).

Kirk, I'. M., and A. E. Ansell. 1992. Authors of fiungal numes. Index of Fungi Supplement. C. A. B. International, Wallingford, Oxon, United Kingdom. $95 \mathrm{pp}$.

Lanjow, J. (Ed.). 1966. International code of botanical no menclature. Intermational Bureau for Plant Taxonomy and Nomenclature, Utrecht, Netherlancls. $402 \mathrm{pp}$.

Libonati-Barnes, D. 198I. Systematics of Tectella, Panellus, Hohenbuehelia and Resupinatus (Tricholomatareae) in the Pacific Northwest. Ph. D. Dissertation, University of Washington, Seattle, Washington. $336 \mathrm{pp}$.

Miller, O. K. 1986. Pleurotoid fungi the Hohenbuehelia-Resupinatus complex in North America. Pp. 111-114. In: Alti del Covegno Internaxionale del 10-15 seltembre 1984, Borgo val di Taro, Italy.

Munsell Color Co., Inc. 1954. Dretermination of soil color: U. S. Dept. Agriculume Handbook. Baltimore, Maryland. $16 \mathrm{pp}$.

Saccardo, P. H. 1887. Sylloge fungorum V. Patavii. $1146 \mathrm{pp}$. Schweinitz, L. v. 1822. Synopsis fungorun Carolinae superioris. Schriften. Naturf. Ges. Leripzig 1: 20-131.

Singer, R. 1951. The "Agaricales" (mushrooms) in nodern taxonomy. Lilloa 22: 1-832.

. 1969. Mycoflora australis. Beih. Nowa Hedurigia 29); $1-405$.

. 1975. The Agaricales in modern taxonomy. 3rd ed. J. Cramer, Vaduz. 912 pp.

. 1989. New taxa and new combination of Agaricales (Diagnoses fungorum novorum Agaricalium, 4). Fieldiana, Bot. 21: 1-133.

- and A. P. L. Digilio. 1951. Prodromo de la flora Agaricina Argentina. Lilloa 25: 6-461.

Wright,J. E. 1955. Revaluation of specific chanaceres in the: genus Tulos/oma Pers. I'ap. Michigan Acal. Sri. a(0: 7!)_ 87. 